\title{
"Internal audit and financial performance of Yemeni commercial banks: Empirical
}

evidence"

\begin{tabular}{|c|c|}
\hline \multirow{4}{*}{ AUTHORS } & Saddam A. Hazaea (iD) \\
\hline & Mosab I. Tabash (iD) \\
\hline & $\begin{array}{l}\text { Jinyu Zhu } \\
\text { Saleh F. A. Khatib (iD) }\end{array}$ \\
\hline & Najib H. S. Farhan (iD \\
\hline ARTICLE INFO & $\begin{array}{l}\text { Saddam A. Hazaea, Mosab I. Tabash, Jinyu Zhu, Saleh F. A. Khatib and Najib H. } \\
\text { S. Farhan (2021). Internal audit and financial performance of Yemeni commercial } \\
\text { banks: Empirical evidence. Banks and Bank Systems, 16(2), 137-147. } \\
\text { doi:10.21511/bbs.16(2).2021.13 }\end{array}$ \\
\hline DOI & http://dx.doi.org/10.21511/bbs.16(2).2021.13 \\
\hline RELEASED ON & Tuesday, 15 June 2021 \\
\hline RECEIVED ON & Monday, 28 December 2020 \\
\hline \multirow[t]{2}{*}{ ACCEPTED ON } & Tuesday, 13 April 2021 \\
\hline & $\left(\right.$ (c) $\mathrm{EY}_{\mathrm{EY}}$ \\
\hline LICENSE & $\begin{array}{l}\text { This work is licensed under a Creative Commons Attribution } 4.0 \text { International } \\
\text { License }\end{array}$ \\
\hline JOURNAL & "Banks and Bank Systems" \\
\hline ISSN PRINT & $1816-7403$ \\
\hline ISSN ONLINE & $1991-7074$ \\
\hline PUBLISHER & LLC "Consulting Publishing Company "Business Perspectives" \\
\hline FOUNDER & LLC "Consulting Publishing Company "Business Perspectives" \\
\hline
\end{tabular}

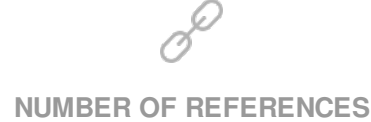

55

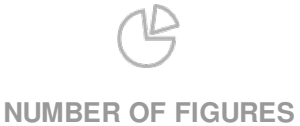

0

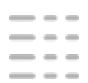

NUMBER OF TABLES

5

(C) The author(s) 2021. This publication is an open access article. 


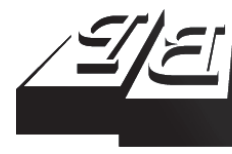

\section{BUSINESS PERSPECTIVES}

()

LLC "CPC "Business Perspectives"

Hryhorii Skovoroda lane, 10, Sumy, 40022, Ukraine

www.businessperspectives.org

Received on: $28^{\text {th }}$ of December, 2020

Accepted on: $13^{\text {th }}$ of April, 2021

Published on: $15^{\text {th }}$ of June, 2021

(c) Saddam A. Hazaea, Mosab I. Tabash, Jinyu Zhu, Saleh F. A. Khatib, Najib H.

S. Farhan, 2021

Saddam A. Hazaea, Ph.D., School of Accounting, Yunnan University of Finance and Economics, China.

Mosab I. Tabash, Ph.D., College of Business, Al Ain University, Al Ain, UAE. (Corresponding author)

Jinyu Zhu, Professor, School of Accounting, Yunnan University of Finance and Economics, China.

Saleh F. A. Khatib, Ph.D., Department of Management, Azman Hashim International Business School, Universiti Teknologi Malaysia, Malaysia.

Najib H. S. Farhan, Ph.D., Ibn Rushd College for Management Science, KSA.
Saddam A. Hazaea (China), Mosab I. Tabash (UAE), Jinyu Zhu (China),

Saleh F. A. Khatib (Malaysia), Najib H. S. Farhan (KSA)

\section{INTERNAL AUDIT AND FINANCIAL PERFORMANCE OF YEMENI COMMERCIAL BANKS: EMPIRICAL EVIDENCE}

\begin{abstract}
This study seeks to verify the contribution of internal audit (IA), especially its role in improving financial performance in Yemeni commercial banks, with a specific focus on three factors, namely: the independence and objectives of IA, the quality of IA and the size of IA. This study reviews some existing literature on the contribution and role of IA in improving financial performance. It relies on available data from questionnaires. 90 questionnaires were distributed to nine commercial banks in Yemen (23 branches) working under the supervision of the Central Bank of Yemen; 81 questionnaires (90\%) were regained and used in the process of analysis. To analyze the data, three analysis approaches were used, including description, correlation, and regression. The results showed that the IA has a significant impact on the overall performance of Yemeni commercial banks. Furthermore, the results showed that the auditors' efficiencies, as well as their financial and accounting experiences, have a significant and positive impact on financial performance. It was revealed that the independence and objectivity of internal auditors are highly insignificant for financial performance. However, the size of IA and the frequency of the auditors' meetings have a negative and significant effect on financial performance. This study provides some recommendations for improving the effectiveness of IA, which in turn will contribute to improving financial performance.
\end{abstract}

Keywords

audit quality, auditor independence, auditor objectivity, Yemen, banks

\section{JEL Classification $\quad$ G21, G34, M42}

\section{INTRODUCTION}

Internal audit (IA) is a basic element of internal control. It is an independent activity carried out by specialists in institutions. Also, IA is a useful tool aimed at supporting administrations in examining regulatory policies to ensure asset protection and the efficiency of data contained in accounting records, which are aimed at increasing higher possible adequacy of productivity. This function is essential for the success of all firms, including banks. Banks attach great importance to protecting their property as they seek to preserve it, especially given its large size and diversified business, to ensure their survival and continuity. Banks have come to attach particular importance to auditing, where auditing is a tool that helps to identify mistakes and fraud, to ensure that the goals of banks are protected, and to confront the economy of their surrounding full of changes, especially in the era of globalization and rapid global changes. IA management is one of the most important departments in banks, where the IA department is the most critical element in evaluating the work of departments in banks. It is the backbone of accounting because this department tracks all financial operations in institutions.

IA is considered one of the most critical monitoring mechanisms used in corporate governance and the external audit, as well as a directive 
(Matarneh, 2011). The quality of IA has a significant and positive impact on the financial performance of institutions (Heil, 2012). The main tasks of an IA are fighting corruption, evaluating financial operations, working to protect assets, evaluating policy and instruction compliance by stakeholders, and improving financial and administrative performance (Staciokas \& Rupsys, 2005). One of the main goals of the IA system is to ensure sound and accurate outputs of accounts and the accounting system represented in financial statements; on the other hand, an effective monitoring IA system provides accurate and sound financial reports and indicators that express the financial position of an institution, which helps senior management evaluate the performance of an organization and take appropriate decisions that contribute to improving performance (Atika, 2006). It has been suggested that the quality of IA has a significant and positive impact on improving financial performance.

Moreover, the audit with quality characteristics in terms of auditors' independence and the implementation of modernized control tools, contributes to improving customer satisfaction, which helps increase financial income (Phan et al., 2020). IA contributes to improving the financial performance of organizations through many factors, the most important of which is the application of professional standards for IA (Ondieki, 2013). Financial performance is the most crucial factor that the capital owners seek as the primary objective of assessing investment (Tarmidi et al., 2019). IA management's enjoyment of its members' independence and efficiency dramatically increases the financial performance of commercial banks (Ondieki, 2013). IA processes by auditors greatly influence the financial performance of institutions by monitoring operations and evaluating work (Aikins, 2011). Through its functions, IA contributes to improving financial performance of Jordanian commercial banks, as well as reducing the risks to which banks may be exposed (Awdat, 2015).

Financial performance is a description of the institution's current status and accurate identification of the areas it used to reach goals by studying the outcome of its business, assets, and liabilities (Farhan \& Al-Mashhadani, 2011). Having reviewed the literature, the question that remained unanswered is how to identify that IA is effective and achieves its objectives in institutions, including commercial banks? According to Oussii and Boulila Taktak (2018), there is a need for more work exploring the IA function from developing markets that have received less attention in the literature. In theory, the answer should be when the IA quality has a positive impact on commercial banks' financial performance. The quality of the IA consists of several factors. This study will discuss three factors such as the independence and objectivity of the internal auditors, the quality of IA, and the size of IA.

This study will contribute significantly to providing shareholders and stakeholders, as well as the members of the bank's management, with a clear understanding of the critical role of IA in commercial banks. In addition to this, it provides a precise reading for the administrative and financial professionals and chief executives of these banks to put IA. In Yemen, IA faces many challenges, perhaps the most important of which is stakeholders' failure to realize the importance of IA as one of the essential factors contributing to preserving the continuity of institutions and improving their financial and administrative performance. Therefore, this is one of the incentives that prompted this pilot study. It is believed that the banking sector is one of the most critical areas on the economic level, which deals with a vast number of individuals and companies; it is based on significant capital and plays a fundamental role in the development and investment wheel. Hence, the importance of the study was to clarify the role of IA units in controlling performance in Yemeni banks, so that they can contribute to identifying this role and discover a mechanism to enhance this role, and then propose appropriate recommendations to support and increase the efficiency of IA performance in detecting errors in the financial statements. 


\section{LITERATURE REVIEW AND HYPOTHESIS DEVELOPMENT}

Internal audit (IA) is considered to be a useful tool aimed at supporting the administration in examining regulatory policies to assure asset protection and the efficiency of data contained in the accounting records aimed at obtaining high adequacy of productivity.

As a result of changes and shifts that occurred in the practice of business, the IA function responded to these changes by providing services and consultations to various parties in institutions, in addition to the assistance in risk management. In Yemen, however, despite many decisions that organize the IA function in the units of the state's administrative apparatus, for example, the issuance of Resolution No. 25 of 1986 and Resolution No. 21 of 1999 that included some legislation on IA, the IA remained the traditional function of exercising control. This is a clear indication that IA in Yemen is faced with a number of challenges, among which there are many important - the scarcity of competencies with adequate experience to practice the profession of auditing, scarcity of modern audit systems, and the lack of an internal control system (Qatinah, 2012). Similarly, Hazaea et al. (2020b) argued that the Yemeni IA system faces many challenges such as the inefficiency of audit members, the lack of financial and accounting experience of members, the weakness of the internal control system, and the lack of independence of the IA. It has been suggested that the function of internal audits is essential for the success of all firms, including banks.

IA department members positively affect activating performance if the auditors possess objective competence and experience (Al-Twaijry et al., 2004). According to agency theory, which is the most common in the literature (Khatib et al., 2020), IA, along with some other factors, contributes to achieving the institutions' goals and maintaining continuity. This theory is concerned with finding solutions to problems that are expected to appear in institutional relationships, for example, managers of institutions and owners, managers of institutions and heads of de- partments, when the goals and desires of corporate managers conflict with agents of shareholders, and thus this theory can be used in this case (Khatib et al., 2021). Adams (1994) reported that agency theory can provide meaningful investigation and research concerning IA. This is in line with Ondieki (2013) who suggested that agency theory can provide evident explanation characteristics of IA and interpretation; also, it can be used to conduct pilot tests to clarify the differences between IA practices.

Despite the growing interest among scholars in investigating the role of IA functions in enhancing corporate performance (e.g., Ahmad et al., 2009; Al-Matari et al., 2017; Cohen \& Sayag, 2010; Drogalas et al., 2015; Poltak et al., 2019), the findings are inconsistent. Also, Oussii and Boulila Taktak (2018) reported that there is a need for more work exploring the IA function from developing markets that have received less attention in the literature. Therefore, this study investigates the impact of three IA related factors on the performance of a financial institution. These factors include the independence and objectivity of the internal auditors, the quality of IA, and the size of IA.

The independence of members of the audit committee (ACs) and internal auditors, while performing their operational and supervisory work, contributes significantly to improving public institutions' financial performance. Moreover, it provides the detection of imbalances on time, which helps assess the work properly (Bansal \& Sharma, 2016). The study by Ojong and Ekponta (2014), which discusses the role of IA in the efficiency of financial performance in Nigerian higher education institutions, revealed that the role of IA in improving financial performance is not very significant, and the reason is the absence of employees' independence from senior management. The existence of internal entirely independent auditors has a positive impact on the financial performance of banks (Aminu et al., 2015). The contribution of the audit to improving the financial performance of banks is related to several things, including the presence of experienced and competent auditors, the auditors obtaining sufficient rights for them, and the extent of the contribution of the institutions' management to overcom- 
ing the difficulties (Tapang \& Ibiam, 2019). The quality of audit represented by the independence of its members and their accounting expertise, in addition to the size of a committee, has a positive relationship and directly affects the financial performance of institutions. These results are consistent with the results of the theory of dependence on resources, which indicated that if the ACs' size is suitable, this contributes to enhancing efficiency in the work, which enhances the financial performance of institutions (Dakhlallh, 2020). The independence of audit members contributes significantly to improving the institutions' financial performance (Commey et al., 2020). Independence of an IA department and the efficiency of its members have an impact on improving commercial banks' performance from an administrative and financial point of view. In contrast, other studies have found that the IA size and the number of managers of IA departments do not affect the improvement of performance (Sakilu \& Kibret, 2015).

IA is seen as a science with extensive experience that can be effectively used in assessing financial resources and helping to improve financial performance (Aikins, 2011). The IA functions are considered one of the most critical tools to improve financial performance through oversight, monitoring, and evaluation processes in public institutions (Diamond, 2002). The existence of an IA system under specific regulations and laws, the observance of these regulations and rules lead to improving financial performance in the banking sector (Asiligwa \& Rennox, 2017). Financial performance is positively affected by the quality of the audit, which is measured by the extent of the independence and efficiency of auditors (Chevers et al., 2016). The quality of the audit process and the continuous follow-up of those in charge of the audit by higher audit departments are critical factors in enhancing financial performance in addition to the stability of those in the audit process, also linked positively with financial performance (Hlaciuc, 2016). The IA members' enjoyment of the professional experience and scientific competence has a positive impact on performance (Christ et al., 2015). Auditing plays a significant role in improving the financial performance of institutions (Chijoke-Mgbame et al., 2020). There is a weak positive impact on financial performance in the presence of an IA enjoying the quality, but in general, this effect does not add significant value to the institutions (Ugwu et al., 2020). The use of the audit as a means of assessing the work of institutions has a positive impact on improving their performance (Hazaea et al., 2020c). The presence of internal auditors with financial and accounting efficiencies significantly contributes to enhancing performance in commercial banks due to reporting errors and abuses on time, which leads to correcting them before they affect performance (Yasin et al., 2020).

Having a sufficient number of qualified auditors has a positive impact on the performance of banks (Aminu et al., 2015). Dianita (2015) reported that the role of the IA in improving financial performance does not have an effect, due to the inefficiency of internal auditors and the limited number of them, making them unable to maximize the financial performance of banking institutions. A study conducted by Alzeban (2020) aimed at evaluating the influence of the IA and ACs on the performance of institutions, showed that if the members of ACs enjoy the independence and experience, the IA size is suitable to exert a positive influence on the institution's performance. Dakhlallh (2020) found that the size of ACs has a positive relationship with financial performance. The size of IA contributes to enhancing the financial performance of organizations through the contribution of all members to the process of controlling operations, which contributes to improving the quality of financial reports (Commey et al., 2020).

Based on the research objectives and the literature review, the research hypotheses are specified as follows:

$H_{i}$ : There is a positive relationship between the independence and objectivity of IA and its ability to control commercial banks' financial performance in Yemen.

$\mathrm{H}_{2}$ : There is a positive relationship between the quality of IA and the financial performance of commercial banks in Yemen.

$H_{3}$ : There is a positive relationship between the size of IA and the financial performance of commercial banks in Yemen. 


\section{METHODOLOGY}

To achieve the research goals, a questionnaire was used as a main tool for data collection to address the study's analytical aspects. 90 questionnaires were distributed to nine commercial banks and 23 branches working under the Central Bank of Yemen's supervision. 81 questionnaires were used in the analysis process. The preparation of the questionnaire's components was conducted based on previous studies and the theoretical framework for the relationship. It includes many paragraphs and questions to obtain answers to them by the internal auditors and members of the ACs working in these banks as the parties through which the IA situation can be assessed and the study objectives evaluated. This is in line with Akintimehin et al. (2019). Five-point Likert scale was used as it is comparatively simple for respondents to use, and responses from such a scale are expected to be reliable (Lam \& Kolic, 2008). It was represented by "Strongly agree", with number 5 and the rate percentage (80-100), "Agree", with number 4 and the rate percentage (60-79), "Neutral", with number 3 and the rate percentage (40-59), "Natural" with number 2 and the rate percentage (20-39), and "Strongly disagree", with number 1 and the rate percentage (0-19). Descriptive analysis was performed along with the regression analysis to ensure the correctness of all variables. This is in line with Steedman (2019). The adapted baseline model for this paper was derived from Otekunrin et al. (2018), as shown below:

$$
\begin{aligned}
& Y=\alpha+\beta_{1} X 1+\beta_{2} X 2+\beta_{3} X 3+\mu_{i t}, \\
& F P=\alpha+\beta_{1} I O I A+\beta_{2} Q I A+\beta_{3} S F I A+\mu_{i t},
\end{aligned}
$$

where FP represents the financial performance of commercial banks; IOIA is the independence and objectivity of internal auditors; QIA is the qualifications of IA, which include (financial and accounting experience, level academic); and SFIA is the size and frequency of IA meetings.

\section{RESULTS}

The questionnaire's reliability and accuracy are essential when using the Likert scale to measure the consistency between the questionnaire items. A Cronbach Alpha test was used that indicates the consistency between the questionnaire expressions. In previous IA studies, a Cronbach Alpha test was used when creating or adapting the questionnaire using the Likert pentatonic scale (Drogalas et al., 2015; Hazaea et al., 2020b). The Cronbach Alpha test is the most used to measure reliability. As shown in Table 1, the value reached 0.707 , which is considered an acceptable percentage. Therefore, the results to be achieved can be trusted when questionnaires are used. The reliability in this questionnaire is greater than $60 \%$, which is the minimum acceptable for measuring reliability. After running the reliability test, the study questionnaire's reliability and the consistency of its paragraphs were confirmed. Thus, it allows ensuring the reliability of the study and its validity when answering questions and trust the analysis results.

Table 1. Reliability statistics

\begin{tabular}{c|c|c|c}
\hline $\begin{array}{c}\text { No. of } \\
\text { questionnaires }\end{array}$ & $\begin{array}{c}\text { No. of } \\
\text { items }\end{array}$ & $\begin{array}{c}\text { Standardized } \\
\text { Cronbach's Alpha }\end{array}$ & $\begin{array}{c}\text { Cronbach's } \\
\text { Alpha }\end{array}$ \\
\hline 81 & 25 & 0.718 & 0.707 \\
\hline
\end{tabular}

Table 2 presents descriptive statistics of all variables employed in this study, including the number of respondents, means, standard deviations, minimum and maximum values. The valid sample number of respondents is 81 . Survey respondents generally rank high on the size and IA meeting frequency, the independence and objectivity of internal auditors, and internal auditors' qualifications. The summary statistics show that internal auditors' independence and objectivity had a mean of 3.644 with a standard deviation of 0.489 . Similarly, the mean value of internal auditors' qualifications is 3.6104 , while the standard deviation is slightly higher than 0.523 . The size and frequency of IA meetings received the highest values with a mean of 3.72, indicating the importance of the size and frequency of IA meetings in relation to financial performance.

As for the correlation between variables, Table 3 provides the correlation matrix between financial performance, the size and frequency of IA meetings, the independence and objectivity of internal auditors, and internal auditors' qualifications. As expected, there is a high correlation between the variables. The size of IA, the frequency of IA 
Table 2. Descriptive analysis results

\begin{tabular}{|c|c|c|c|c|c|}
\hline Variable & $\mathbf{N}$ & Minimum & Maximum & Mean & Std. deviation \\
\hline FA & 81 & 1 & 5 & 3.3302 & 0.71132 \\
\hline IOIA & 81 & 1.86 & 4.57 & 3.6437 & 0.48923 \\
\hline QIA & 81 & 2.33 & 4.89 & 3.6104 & 0.52326 \\
\hline SFIA & 81 & 1.8 & 5 & 3.7235 & 0.58187 \\
\hline Valid $N$ (listwise) & 81 & - & & & \\
\hline
\end{tabular}

Table 3. Correlation matrix

\begin{tabular}{|c|c|c|c|c|c|}
\hline Variable & Descriptions & FP & IOIA & QIA & SFIA \\
\hline \multirow{2}{*}{ FP } & Pearson Correlation & 1 & - & - & - \\
\hline & Sig. (2-tailed) & - & - & - & - \\
\hline \multirow{2}{*}{ IOIA } & Pearson Correlation & $.618^{* *}$ & 0.1 & - & - \\
\hline & Sig. (2-tailed) & 0 & - & - & - \\
\hline \multirow{2}{*}{ QIA } & Pearson Correlation & $.522^{* *}$ & $.559^{* *}$ & 1 & - \\
\hline & Sig. (2-tailed) & 0 & 0 & - & - \\
\hline \multirow{2}{*}{ SFIA } & Pearson Correlation & $-.263^{*}$ & -0.088 & 0.018 & 1 \\
\hline & Sig. (2-tailed) & 0.018 & 0.434 & 0.876 & - \\
\hline
\end{tabular}

meetings, and the independence and objectivity of internal auditors are positively correlated with financial performance, while there is a negative and significant association between the qualifications of internal auditors and firm performance. The table shows that there is no any multicollinearity among the variables as none of the absolute value of the coefficient is greater than 0.8. Gujarati and Porter (2009) recommend 0.8 at the start at which multicollinearity concerns may hurt the regression analysis. All variables' correlation values confirm no multicollinearity as none of them correlates over 0.8 .

In addition to the above analysis, the independence of error terms was tested using the DurbinWatson statistic (DW). This test is generally used to detect the autocorrelation between the independent variables (Khatib \& Nour, 2021). The value of the DW test near 2 indicates non-autocorrelation among the independent variables (Hair et al., 1998). Watson statistic ranges in value from 0 to 4 . Table 4 shows that the model's DW value (1.99) is close to 2, indicating no autocorrelation.
The results clearly show that the $\mathrm{R}$ Square value of .479's is evidence that the independent variables are sufficient to explain the financial performance at a ratio of $47.9 \%$.

To test the research hypotheses, as it is shown in Table 5, regression was performed to all independent variables against the performance of commercial banks, including IA independence, IA quality and IA size. Also, the Variance-Inflatory Factor (VIF) test was carried out to confirm the absence of multicollinearity. The value of VIF for all predictors was less than 10 (Gujarati \& Porter, 2009), indicating that the independent variables do not interrelate with each other. Furthermore, the estimation results are presented in Table 5, which shows the coefficients of the independence and objectivity of internal auditors, internal auditors' qualifications, and the size and frequency of IA meetings at a significant level of 5 per cent. It has been found that the coefficient of independence and objectivity of internal auditors are highly insignificant with a positive effect on the financial performance of Yemeni commercial banks.

Table 4. Durbin-Watson test

\begin{tabular}{c|c|c|c|cc|cc}
\hline Model & R square & $\begin{array}{c}\text { Adjusted } \\
\text { R square }\end{array}$ & $\begin{array}{c}\text { Std. error } \\
\text { of the } \\
\text { estimate }\end{array}$ & $\begin{array}{c}\text { R square } \\
\text { change }\end{array}$ & F change & Sig. F change & Durbin-Watson \\
\hline 1 & .479 & .459 & .52343 & .479 & 23.581 & .000 & 1.99 \\
\hline
\end{tabular}


Table 5. Multiple regression results

\begin{tabular}{|c|c|c|c|c|c|c|c|}
\hline \multirow[t]{2}{*}{ Model } & \multicolumn{2}{|c|}{$\begin{array}{c}\text { Unstandardized } \\
\text { coefficients }\end{array}$} & \multirow{2}{*}{$\begin{array}{c}\begin{array}{c}\text { Standardized } \\
\text { coefficients }\end{array} \\
\text { Beta }\end{array}$} & \multirow[t]{2}{*}{ T-statistic } & \multirow[t]{2}{*}{ Sig. } & \multicolumn{2}{|c|}{ Collinearity statistics } \\
\hline & B & Std. error & & & & Tolerance & VIF \\
\hline Constant & .661 & .625 & - & 1.057 & - & - & - \\
\hline IOIA & .643 & .145 & .442 & 4.428 & .294 & .678 & 1.474 \\
\hline QIA & .379 & .135 & .279 & 2.799 & .000 & .683 & 1.463 \\
\hline SFIA & -.280 & .101 & -.229 & -2.760 & .006 & .986 & 1.014 \\
\hline
\end{tabular}

Therefore, hypothesis 1 cannot be accepted. The coefficient of the qualifications of internal auditors is statistically significant and positively related to financial performance of Yemeni commercial banks, which indicates that the financial and accounting efficiency in terms of the accounting and financial expertise, and professional knowledge of auditing standards enhances the financial performance in commercial banks. Hence, hypothesis 2 can be accepted. Finally, the third hypothesis indicates a negative relationship between IA size (ACs members) and the financial performance in commercial banks, and this association is significant $(\mathrm{p}>0.05)$. This indicates that financial performance is inversely related to the size of the ACs in the banks under investigation.

\section{DISCUSSION}

For independence and objectivity of internal auditors: Through the previous results, it became clear that the independence of IA members and the members of ACs had an insignificant and positive impact on performance. These outcomes are inconsistent with Hazaea et al. (2020b) who argue that the independence of IA members (ACs) contributes to strengthening and improving the performance of institutions, including commercial banks, and leads to improved financial reporting. Banking performance can be improved by enhancing the organizational IA independence (Bett, 2014). This is also confirmed by Ibrahim et al. (2019).
As for the qualification of internal auditors: Through the previous results, it became clear that the qualifications of internal auditors, including the financial and accounting experience, professional knowledge of auditing standards, had an important and positive impact on the bank's performance. These outcomes are in line with Newman and Comfort (2018) who reported that the financial and accounting expertise of auditors has a positive correlation in developing financial performance, since results have proven large correlation and have also proven their capabilities in improving performance. Risk management, annual risk-based planning, following auditing, and auditing standards contribute significantly to enhancing financial performance because it allows institutions to discover risks in a timely manner, which enhances transparency and accountability (Kasiva, 2012).

For size and meeting frequency: Through the previous results, the size and meeting frequency of internal auditors had an important and positive insignificant impact on the bank's financial performance. These outcomes are compatible with Dharmadasa et al. (2014) who reported that the presence of a large number of auditors without the need for them can lead to negative results due to the lack of focus and the desire to achieve the goal due to the dependence of the auditors on each other. This may affect their knowledge levels and professional skills (Drakos \& Bekiris, 2010). These results are inconsistent with Ojeka et al. (2014) and Hazaea et al. (2020a) who reported that the size of ACs, IA, and auditor meeting frequency have a constructive association with financial performance.

\section{CONCLUSION}

This study aims to evaluate the impact of internal audit (IA) on the financial performance of Yemeni commercial banks. The initial analysis showed that IA has a significant impact on overall performance. The coefficient of independence and objectivity of internal auditors is highly insignificant, with a pos- 
itive impact on Yemeni commercial banks' financial performance. It has been found that the auditors' efficiency and their financial and accounting experiences have a significant impact on performance. But the finding revealed that IA size and the frequency of the auditors' meetings have a negative and significant effect. Based on the results obtained, the following recommendations are presented for future implementation: Bank management must work to raise the level of auditors and develop their capacity by doing the following: firstly, special courses on international professional standards and necessary training for internal auditors are recommended. This will help them understand the IA system's modus operandi and, thus, improve their performance. Secondly, a regulatory body is needed that will monitor every unit's performance in banks and demand its periodic reports. Also, internal auditors' independence should be enforced so that they can perform their duties optimally. This paper is important to clarify the image and role of IA in commercial banks, making them more professional and competent. It will help stakeholders assess the role that IA plays as one of the control systems in Yemeni commercial banks to protect their property. Also, the study will help explain the factors that make an assessment of importance and high efficiency, as well as potential for enhanced performance. Researchers will improve their IA capabilities and knowledge to be committed to ethical and professional standards as required. Finally, this paper is beneficial to stakeholders, researchers, and commercial bank managers.

Like other studies, this study is not without its limitations. This study was limited to nine commercial banks operating in the Yemeni banking sector. Moreover, it was limited to clarifying the IA effect on financial performance without considering its role in other areas. Future studies could expand the scope of research and the sample to include government banks and public institutions in general, with more research needed to determine the difficulties and challenges faced by IA in Yemeni commercial banks. Future studies can also investigate the impact of central banks on commercial banks with IA and related operations.

\section{AUTHOR CONTRIBUTIONS}

Conceptualization: Saddam A. Hazaea, Mosab I. Tabash.

Data curation: Jinyu Zhu.

Formal analysis: Saddam A. Hazaea, Saleh F. A. Khatib.

Funding acquisition: Saleh F. A. Khatib.

Investigation: Saddam A. Hazaea, Mosab I. Tabash, Saleh F. A. Khatib, Najib H. S. Farhan.

Methodology: Jinyu Zhu.

Project administration: Najib H. S. Farhan.

Software: Jinyu Zhu.

Supervision: Mosab I. Tabash, Saleh F. A. Khatib, Najib H. S. Farhan.

Validation: Najib H. S. Farhan.

Visualization: Jinyu Zhu.

Writing - original draft: Saddam A. Hazaea.

Writing - reviewing \& editing: Mosab I. Tabash.

\section{REFERENCES}

1. Adams, M. B. (1994). Agency

Theory and the Internal Audit. Managerial Auditing Journal, 9(8), 8-12. https://doi. org/10.1108/02686909410071133

2. Ahmad, N., Othman, Rad., Othman, Roh., \& Jusoff, K. (2009). The effectiveness of internal audit in Malaysian public sector
Journal of Modern Accounting and Auditing, 5(9), 53-63. Retrieved from http://repo.uum.edu. my/12749/1/JM.pdf

3. Aikins, S. (2011). An examination of government internal audits' role in improving financial performance. Public Finance and Management, 11(4), 306-337.
Retrieved from https://spaef.org/ article/1323/An-Examinationof-Government-Internal-AuditsRole-in-Improving-FinancialPerformance

4. Akintimehin, O. O., Eniola, A. A., Alabi, O. J., Eluyela, D. F., Okere, W., \& Ozordi, E. (2019). Social capital and its effect on business 
performance in the Nigeria informal sector. Heliyon, 5(7), e02024. https://doi.org/10.1016/j. heliyon.2019.e02024

5. Al-Matari, Y. A., Abdullah, S., Mohammed, S., \& Al-Matari, E. M. (2017). Audit Committee Activities and the Internal Control System of Commercial Banks Operating in Yemen. International Review of Management and Marketing, 7(1), 191-196. Retrieved from https://www.econjournals.com/index.php/irmm/ article/view/2899/pdf

6. Al-Twaijry, A. A. M., Brierley, J. A., \& Gwilliam, D. R. (2004). An examination of the relationship between internal and external audit in the Saudi Arabian corporate sector. Managerial Auditing Journal, 19(7), 929-944. https://doi. org/10.1108/02686900410549448

7. Alzeban, A. (2020). The relationship between the audit committee, internal audit and firm performance. Journal of Applied Accounting Research, 21(3), 437-454. https://doi.org/10.1108/ JAAR-03-2019-0054

8. Aminu, B., Aisha, M., \& Muhammad, T. (2015). The effect of board size and composition on the financial performance of banks in Nigeria. African Journal of Business Management, 9(16), 590-598. https://doi.org/10.5897/ AJBM2015.7797

9. Asiligwa, M., \& Rennox, G. (2017). The Effect of Internal Controls on the Financial Performance of Commercial Banks in Kenya. IOSR Journal of Economics and Finance, 8(3), 92-105. https://doi. org/10.9790/5933-08030492105

10. Atika. (2006). The role of internal auditing in evaluating the financial performance of the economic establishment.

11. Awdat, A. A. (2015). The impact of the internal audit function to improve the financial performance of commercial banks in Jordan. Research Journal of Finance and Accounting, 6(3), 217-226. Retrieved from https://www.coursehero.com/ file/29094399/19962-22494-1-PBpdf/
12. Bansal, N., \& Sharma, A. K. (2016). Audit Committee, Corporate Governance and Firm Performance: Empirical Evidence from India. International Journal of Economics and Finance, 8(3), 103. https://doi.org/10.5539/ijef. v8n3p103

13. Bett, C. C. (2014). The Relationship between Effectiveness of Internal Audit Function and Financial Performance of Companies Listed in Nairobi Securities Exchange. International Journal of Audit and Finance, 11(7), 98-103. Retrieved from https://www.semanticscholar. org/paper/THE-RELATIONSHIPBETWEEN-EFFECTIVENESSOF-INTERNAL-Bett/9478bc12f4c fae17302a22c427b231ad2534c0b5

14. Chevers, D., Lawrence, D., Laidlaw, A., \& Nicholson, D. (2016). The effectiveness of internal audit in Jamaican commercial banks. Accounting and Management Information Systems, 15(3), 522-541. Retrieved from http:// online-cig.ase.ro/RePEc/ami/articles/15_3_4.pdf

15. Chijoke-Mgbame, A. M., Boateng, A., \& Mgbame, C. O. (2020). Board gender diversity, audit committee and financial performance: evidence from Nigeria. Accounting Forum, 44(3), 262-286. https://doi.org/10.1080/0 1559982.2020 .1766280

16. Christ, M. H., Masli, A., Sharp, N. Y., \& Wood, D. A. (2015). Rotational internal audit programs and financial reporting quality: Do compensating controls help? Accounting, Organizations and Society, 44, 37-59. https://doi. org/10.1016/j.aos.2015.05.004

17. Cohen, A., \& Sayag, G. (2010). The Effectiveness of Internal Auditing: An Empirical Examination of its Determinants in Israeli Organisations. Australian Accounting Review, 20(3), 296-307. https://doi.org/10.1111/j.18352561.2010.00092.x

18. Commey, J., Osabutey, W., \& Afoley, L. (2020). Effects of Internal Audit Committee Size on Profitability. International Journal of Academic Research in Business and Social Sciences, 10(5), 221-228. https://doi.org/10.6007/IJARBSS/ v10-i5/7189

19. Dakhlallh, M. M. (2020). Audit Committee and Tobin's $\mathrm{Q}$ as a Measure of Firm Performance among Jordanian Companies. Journal of Advanced Research in Dynamical and Control Systems, 12(1), 28-41. https:// doi.org/10.5373/JARDCS/ V12I1/20201005

20. Dharmadasa, P., Gamage, P., \& Herath, S. K. (2014). Corporate governance, board characteristics and firm performance: Evidence from Sri Lanka. South Asian Journal of Management, 21(1), 7-31. Retrieved from https://www. proquest.com/openview/c4e225cb 0c6094ad7f03781ad4edbff1/1?pqorigsite $=$ gscholar $\& \mathrm{cbl}=46967$

21. Diamond, M. J. (2002). The role of internal audit in government financial management: an international perspective (IMF Working Paper No. WP/02/94). International Monetary Fund. Retrieved from https://www.imf. org/external/pubs/ft/wp/2002/ wp0294.pdf

22. Dianita, M. (2015). Role of the Internal Auditor Influence and Good Corporate Governance in Banking Financial Performance Against State Owned Corporation. International Journal of Business and Administrative Studies, 1(4), 176-179. https://doi.org/10.20469/ ijbas.10006-4

23. Drakos, A. A., \& Bekiris, F. V. (2010). Endogeneity and the relationship between board structure and firm performance: a simultaneous equation analysis for the Athens Stock Exchange. Managerial and Decision Economics, 31(6), 387-401. https:// doi.org/10.1002/mde.1492

24. Drogalas, G., Karagiorgos, T., \& Arampatzis, K. (2015). Factors associated with Internal Audit Effectiveness: Evidence from Greece. Journal of Accounting and Taxation, 7(7), 113-122. https:// doi.org/10.5897/JAT2015.0182

25. Farhan, S., \& Al-Mashhadani, A. (2011). Corporate governance and strategic financial performance of 
banks. Dar Al-Safa for Publishing and Distribution, Amman, Jordan.

26. Gujarati, D. N., \& Porter, D. C. (2009). Basic Econometrics (5th ed.). Boston: McGraw-Hill Irwin.

27. Hair, J., Anderson, R., Tatham, R., \& Black, W. (1998). Multivariate data Analysis (5th ed.). New Jersey: Pearson Prentice Hall.

28. Hazaea, S. A., Tabash, M. I., Khatib, S. F. A., Zhu, J., \& Alkuhali, A. A. (2020a). The Impact of Internal Audit Quality on Financial Performance of Yemeni Commercial Banks: An Empirical Investigation. The Journal of Asian Finance, Economics and Business, 7(11), 867-875. https:// doi.org/10.13106/jafeb.2020.vol7. no11.867

29. Hazaea, S. A., Zhu, J., Alsharabi, N., Khatib, S. F. A., \& Yueying, L. L. (2020b). On The Effectiveness of Audit Committee Characteristics in Commercial Banks: Evidence from Yemen. Journal of Critical Reviews, 7(18), 2096-2115. https://doi. org/10.31838/jcr.07.18.263

30. Hazaea, S. A., Zhu, J., Khatib, S. F. A., \& Arshad, M. (2020c). A Comparative Study of The Internal Audit System Between China and The Gulf Cooperation Council Countries. Proceeding on Business, Economy, Management and Social Studies towards Sustainable Economy, 1(1), 1-7. Retrieved from http://proceeding.rsfpress. com/index.php/bemss/article/ view/5

31. Heil, D. (2012). The influence of the auditor on the earnings quality of their clients (Master's Thesis). Retrieved from https:// thesis.eur.nl/pub/10237/MA006Heil_306477.docx

32. Hlaciuc, E. (2016). The Challenges of Corporate Governance and Audit in Relation to Financial Performance-Trends, Limitations and Directions to Follow. The USV Annals of Economics and Public Administration, 16(2), 126-136. Retrieved from https://ideas.repec. org/a/scm/usvaep/v16y2016i2(24) p126-136.html
33. Ibrahim, H., Ouma, C., \& Koshal, J. (2019). Effect of audit committee independence on the financial performance of insurance firms in Kenya. International Journal of Research in Business and Social Science (2147-4478), 8(6), 15-24. https://doi.org/10.20525/ijrbs. v8i6.501

34. Kasiva, M. V. (2012). The impact of risk based audit on financial performance in commercial banks in Kenya (Master's Thesis). University of Nairobi. Retrieved from http://erepository.uonbi.ac.ke/bitstream/handle/11295/15058/Kasiva_The\%20 impact $\% 20$ of $\% 20$ risk $\% 20$ based\%20audit\%20on\%20financial\%20performance $\% 20 \mathrm{in} \% 20$ Commercial\%20Banks\%20in\%20 Kenya.pdf?sequence $=3$

35. Khatib, S. F. A., \& Nour, A.-N. I. (2021). The Impact of Corporate Governance on Firm Performance During The COVID-19 Pandemic: Evidence from Malaysia. Journal of Asian Finance, Economics and Business, 8(2), 943-952. https:// doi.org/10.13106/jafeb.2021.vol8. no2.0943

36. Khatib, S. F. A., Abdullah, D. F., Elamer, A. A., \& Abueid, R. (2021). Nudging toward diversity in the boardroom: A systematic literature review of board diversity of financial institutions. Business Strategy and the Environment, 30(2), 985-1002. https://doi. org/10.1002/bse. 2665

37. Khatib, S. F. A., Abdullah, D. F., Hendrawaty, E., \& Yahaya, I. S. (2020). Corporate governance mechanisms and capital structure. Journal of Critical Reviews, 7(16), 463-471. Retrieved from https:// www.academia.edu/43184284/ Corporate_Governance_Mechanisms_and_Capital_Structure

38. Lam, T. C. M., \& Kolic, M. (2008). Effects of semantic incompatibility on rating response. Applied Psychological Measurement, 32(3), 248-260. https://doi. org/10.1177/0146621607301094

39. Matarneh, G. F. A. (2011) Factors Determining the Internal Audit Quality in Banks: Empirical Evidence from Jordan.
International Research Journal of Finance and Economics, 73, 110-119. Retrieved from https:// www.academia.edu/8488336/ Factors_Determining_the_Internal_Audit_Quality_in_Banks

40. Newman, W., \& Comfort, M. (2018). Investigating the value creation of internal audit and its impact on company performance. Academy of Entrepreneurship Journal, 24(3), 1-21. Retrieved from https://www.abacademies. org/articles/Investigating-the-value-creation-of-internal-audit-andits-1528-2686-24-3-172.pdf

41. Ojeka, S., Iyoha, F. O., \& Obigbemi, I. F. (2014). Effectiveness of audit committee and firm financial performance in Nigeria: an empirical analysis. Journal of Accounting and Auditing: Research \& Practice, 2014, 301176. https:// doi.org/10.5171/2014.301176

42. Ojong, N., \& Ekponta, P. (2014). The effect of internal audit function on the financial performance of tertiary institutions in Nigeria. International Journal of Economics, Commerce and Management, 2(10), 1-14. Retrieved from http:// ijecm.co.uk/wp-content/uploads/2014/10/21036.pdf

43. Ondieki, N. M. (2013). Effect of internal audit on financial performance of commercial banks in Kenya (Master's Thesis). University of Nairobi. Retrieved from http://erepository.uonbi.ac.ke/bitstream/handle/11295/59308/ondieki_effect+o $\mathrm{f}+$ internal+audit+on+financial+pe rformance+of+commercial+banks + in + kenya.pdf? sequence $=3$

44. Otekunrin, A. O., Nwanji, T. I., Agba, D. Z., Olowookere, J. K., Fakile, S. A., Ajayi, S. A., \& Oladiran, T. (2018). Outsourcing of accounting services and strategic cost management method: A case study of Dangote flour PLC and Doyin Investment Nig. LTD. Proceedings of the $32 n d$ International Business Information Management Association Conference, 8452-8465.

45. Oussii, A. A., \& Boulila Taktak, N. (2018). The impact of internal 
audit function characteristics on internal control quality. Managerial Auditing Journal, 33(5), 450-469. https://doi.org/10.1108/ MAJ-06-2017-1579

46. Phan, T. T. H., Lai, L. A., Le, T T., Tran, D. M., \& Tran, D. T. (2020). The impact of audit quality on performance of enterprises listed on Hanoi Stock Exchange. Management Science Letters, 10(1), 217-224. https://doi.org/10.5267/j. msl.2019.8.001

47. Poltak, H., Sudarma, M., \& Purwanti, L. (2019). The Determinants of the Effectiveness of Internal Audits with Management Support as the Moderating Variable. International Journal of Multicultural and Multireligious Understanding, 6(1), 33. https://doi.org/10.18415/ ijmmu.v6i1.483

48. Qatinah, A. (2012). Banking sector reforms in Yemen. Marburg University.

49. Sakilu, O. B., \& Kibret, B. G. (2015). Determinants of the
Financial Performances of Commercial Banks in Ethiopia: From Internal Corporate Governance Practice Perspective. Journal of Eastern European and Central Asian Research, 2(1), 1-10. https://doi.org/10.15549/jeecar. v2i1.82

50. Staciokas, R., \& Rupsys, R. (2005). Internal audit and its role in organizational government. Management of Organizations: Systematic Research, 12(33), 169181. Retrieved from https://www. proquest.com/openview/1543003d d9a53c8beda8550cc06b3e5a/1?pqorigsite $=$ gscholar $\& \mathrm{cbl}=28845$

51. Steedman, R. (2019). Nairobibased middle class filmmakers and the production and circulation of transnational cinema. Poetics, 75 , 101333. https://doi.org/10.1016/j. poetic.2018.11.002

52. Tapang, A. T., \& Ibiam, O. (2019). Internal Audit and Financial Performance of Micro Finance Banks in Nigeria. International Journal of Social Sciences and Management Research, 5(4), 95-
107. Retrieved from https://iiardpub.org/get/IJSSMR/VOL.\%20 5\%20NO.\%204\%202019/INTERNAL\%20AUDIT\%20AND\%20 FINANCIAL.pdf

53. Tarmidi, D., Fitria, G. N., \& Ahmad, Z. (2019). Financial Performance and Audit Quality: Comparative Study of Investor Reaction. Scholars Bulletin, 5(12), 828-833. https://doi.org/10.36348/ sb.2019.v05i12.019

54. Ugwu, C. C., Aikpitanyi, L. N., \& Idemudia, S. (2020). The Effect of Audit Quality on Financial Performance of Deposit Money Banks (Evidence from Nigeria). Journal of Economics and Business, 3(1), 270-281. https://doi. org/10.31014/aior.1992.03.01.196

55. Yasin, H. N., Rashid, H. H., Mustafa, J. M., \& Muhamad, A. L. K. W. (2020). Effects of internal audit function and internal control systems on financial performance. Cihan University, Kurdistan Region, Iraq. 